\title{
Spray-Dried Structured Lipid Carriers for the Loading of Rosmarinus officinalis: New Nutraceutical and Food Preservative
}

\author{
Iara Baldim ${ }^{1,2} \oplus$, Claudia R. F. Souza ${ }^{1}\left(\mathbb{D}\right.$, Alessandra Durazzo ${ }^{3}{ }^{\circ}$, Massimo Lucarini ${ }^{3}$, \\ Antonello Santini ${ }^{4, * \mathbb{D}}$, Eliana B. Souto $2,5, * \mathbb{D}$ and Wanderley P. Oliveira ${ }^{1, * \mathbb{D}}$ \\ 1 Faculty of Pharmaceutical Sciences of Ribeirão Preto, University of São Paulo, Av. do Café s/n, Ribeirão \\ Preto, SP, São Paulo 14040-903, Brazil; iara.baldim@usp.br (I.B.); souzacrf@gmail.com (C.R.F.S.) \\ 2 CEB-Centre of Biological Engineering, University of Minho, Campus de Gualtar, 4710-057 Braga, Portugal \\ 3 CREA-Research Centre for Food and Nutrition, Via Ardeatina 546, 00178 Rome, Italy; \\ alessandra.durazzo@crea.gov.it (A.D.); massimo.lucarini@crea.gov.it (M.L.) \\ 4 Department of Pharmacy, University of Napoli Federico II, Via D. Montesano 49, 80131 Napoli, Italy \\ 5 Faculty of Pharmacy, Department of Pharmaceutical Technology, University of Coimbra, Pólo das Ciências \\ da Saúde, Azinhaga de Santa Comba, 3000-548 Coimbra, Portugal \\ * Correspondence: asantini@unina.it (A.S.); ebsouto@ff.uc.pt (E.B.S.); wpoliv@fcfrp.usp.br (W.P.O.)
}

Received: 9 June 2020; Accepted: 7 August 2020; Published: 13 August 2020

check for updates

\begin{abstract}
Rosemary, an aromatic herb with significant antioxidative activity, is frequently used as food preservative and a source of nutraceuticals. Its antioxidant effect is mainly related to the presence of phenolic compounds, molecules considerably unstable and prone to irreversible physicochemical changes when exposed to external agents. We here proposed the loading of rosemary into structured lipid systems to improve its physicochemical properties. Four formulations were prepared using the same amount of rosemary lyophilized extract. The lipid phase was composed of stearic acid and oleic acid, and the aqueous phase, a varying combination of drying carriers (whey protein concentrate or gum Arabic) and surfactant (Poloxamer 188). The formulations were sonicated, spray-dried, and the obtained powders were characterized regarding the density $(0.18 \mathrm{~g} / \mathrm{mL}$ to $0.26 \mathrm{~g} / \mathrm{mL})$, particle size distribution $(7 \mu \mathrm{m}$ and $52 \mu \mathrm{m})$, and water solubility $(29 \%$ to $48 \%)$. The antioxidant activity was determined by applying $\mathrm{ABTS}^{\bullet+}$ radical-scavenging assay and the results expressed per gram of lyophilized extract (150.6 $\mu \mathrm{mol}$ Trolox/g to $376.4 \mu \mathrm{mol}$ Trolox/g), with a significantly lower/higher result seen for formulations containing gum Arabic and a higher concentration of Poloxamer. The prepared systems may have potential applications as preservative in foodstuff and as nutraceutical.
\end{abstract}

Keywords: Rosmarinus officinalis; antioxidant activity; spray-dryer; structured lipid carriers; food preservative; nutraceuticals

\section{Introduction}

There has been an increasing interest in the use of natural antioxidants [1-4] to replace the synthetic ones [5-10]. This trend is motivated by some negative aspects of the synthetic antioxidants, such as some deleterious secondary effects [11] and the concern about their toxicological long-term effects [12]. Studies have also demonstrated that butylated hydroxyanisole (BHA) and butylated hydroxytoluene (BHT), the two most commonly employed antioxidants in the industry, are associated with DNA damage induction $[13,14]$.

Herbs, spices, and essential oils are well known to possess antioxidant activity [15-22]. Rosmarinus officinalis is a common household plant [23], with significant antioxidant properties [24,25], being broadly applied in various fields, including cosmetics [26], as food preservative [27], 
as nutraceutical, and in phytomedicines $[16,28,29]$. These properties have been attributed to rosemary's polyphenolic composition, which includes mainly rosmarinic acid [30], carnosic acid, and carnosol [31].

The antioxidant properties are the expression of combined action of bioactive components in a matrix [32]. Several methodologies are commonly used for this evaluation [33], such as the Trolox equivalent antioxidant capacity (TEAC), the total radical-trapping antioxidant parameter (TRAP), the oxygen radical absorbance capacity (ORAC), the ferric-reducing/antioxidant power (FRAP), and the 2,2-diphenyl-1-picrylhydrazyl radical $\left(\mathrm{DPPH}^{\bullet}\right)$ scavenging method $[9,10]$. Each essay has its peculiarities of mechanism and methodology to evaluate the antioxidant properties; therefore, it is recommended to use different tests for an adequate analysis.

Herbs are routinely marketed as standardized products (of known bioactive content) under different dosage forms. Recently, the use of standardized dried extracts is a trend of the industry. Encapsulation of phytochemicals in drug delivery systems is a suitable way to improve their physical-chemical properties, prevent their degradation, and also to improve their bioavailability in biological settings [34,35]. The highly lipophilic nature of rosemary antioxidants makes encapsulation in lipid systems the most suitable. The solid form has clear advantages over the conventional liquid form, namely: higher physicochemical and microbiological stability; ease of standardization; a higher bioactive content; ease in logistics processes; and the possibility to be used under distinct dosage forms $[34,36]$. The spray-drying, one of the most used drying techniques, is widely used to standardize phytopharmaceutical ingredients, ensuring product efficacy, safety, and quality [37]. It is also a widely used approach for the microencapsulation of compounds of different chemical nature, producing microspheres or microcapsules, according to the initial feed material [34,38,39].

The selection of the appropriated drying carriers is a key parameter to obtain a stable product [40]. The composition of the feed formulation directly influences the spray-dried product recovery since it affects the glass transition temperature of the composition [41]. Carbohydrates are examples of widely used wall material to encapsulate food ingredients by spray-drying [42-44]. On the one hand, these materials offer several desirable properties for encapsulating agents, such as good protection of flavors against oxidation, low viscosity at high solids contents (such as cellulose) [45], good solubility in water, versatility, and GRAS (generally recognized as safe) status [46]. In contrast, most lack the interfacial properties, important characteristics associated with some encapsulation materials (e.g., milk proteins) [47]. Nevertheless, since they have a higher cost than carbohydrates, it becomes disadvantageous to use exclusively proteins for the encapsulation process. An interesting approach to improve the encapsulating properties of a system is the use of blends of carbohydrates and proteins, combining the advantages of both ingredients [48]. Gum Arabic is another effective wall material considering its emulsifying properties due to the protein portion of its structure [49].

It is also noteworthy that pharmaceutical and food lipid formulations prioritize the use of natural components $[15,20,50-52]$. Meanwhile, the possibility of using generally recognized as safe and natural ingredients expands the applicability of lipid nanoparticles not only in the delivery of drugs but also in several other fields and market segments $[50,51,53,54]$. The solid lipid matrix can be composed of waxes, fatty acids, glycerides, and steroids. Stearic acid, a long-chain saturated fatty acid, is a constituent of animal fats. Properties such as melting point above room and body temperatures, good biocompatibility, and reduced toxicity make this a widely used pharmaceutical excipient for drug delivery [52,55]. The presence of a liquid lipid (oil) reduces the melting point of solid lipid and creates imperfections in the lipid matrix, which increases the loading capacity, especially for lipophilic compounds [53,54,56]. Oleic acid is a fatty acid found in several animal and plant sources [57], commonly used as an emulsifying agent and penetration enhancer [53].

This study aimed to produce powdered dried solid lipid dispersions containing Rosmarinus officinalis lyophilized extract and evaluate the influence of drying adjuvants (whey protein and Arabic gum) and surfactant concentration (Poloxamer 188) on the spray-drying process, physicochemical characteristics of the powder, and antioxidant properties of the dried product. 


\section{Materials and Methods}

\subsection{Materials}

6-hydroxyl-2,5,7,8-tetra methylchroman-2-carboxylic acid (Trolox), ABTS, dehydrated quercetin and gallic acid were purchased from Sigma-Aldrich Chemical Co (St Louis, MO, USA); ethanol and potassium per-sulphate were purchased from LabSynth (Diadema, SP, Brazil); Rosmarinus officinalis leaves (Santos Flora, São Paulo, Brazil), stearic acid (Viafarma, São Paulo, Brazil), oleic acid (LabSynth, São Paulo, Brazil), Poloxamer 188 (kindly donated by BASF, Brazil), Arabic gum (NEXIRA, Brazil), whey protein (Arla Foods Ingredients S.A., Argentina), ethanol (LabSynth, Diadema, SP, Brazil), and ultrapure water was obtained by Milli $Q$ filtration system (Millipore, Germany).

\subsection{Preparation of Lyophilized R. Officinalis Extract}

Hydroalcoholic extract of milled leaves of Rosmarinus officinalis was prepared by dynamic maceration using ethanol $70 \% v / v$ as the solvent and a plant to solvent ratio of 1:10 (w/v). The glass container was coupled to a thermostatic bath at $50{ }^{\circ} \mathrm{C}$ for $60 \mathrm{~min}$. At the end of the process, the extract was vacuum filtered and concentrated in a rotary evaporator $\left(55^{\circ} \mathrm{C}\right.$ and $\left.600 \mathrm{mmHg}\right)$. The concentrated extract was subsequently lyophilized in a Thermo Fisher Micromodulyo-115.

\subsection{Preparation of Lipid Formulations}

Based on the components' proportions and process conditions obtained in previous preformulation studies conducted by our research group, with some modifications [41], four lipid formulations were prepared in a single trial, containing the same amount of rosemary lyophilized extract (Table 1). The oil phase (stearic acid and oleic acid) was heated to $75^{\circ} \mathrm{C}$ to melt the lipid mixture. The aqueous phase, composed by water, rosemary extract solubilized in ethanol, drying carrier (whey protein or gum Arabic, depending on the formulation), and surfactant (Poloxamer 188), was heated at the same temperature $\left(75^{\circ} \mathrm{C}\right)$, and slowly added to the oil phase. The formed preformulation was then sonicated in an ultrasonic sonicator VCX750 (SONICS Vibracell, Newton, PA, USA), using a 13 mm probe under $20 \mathrm{kHz}$ of frequency and intensity of $50 \%$ for $5 \mathrm{~min}$, prior to the drying.

Table 1. Composition of the lipid systems containing R. officinalis lyophilized extract $(\% w / w)$.

\begin{tabular}{|c|c|c|c|c|c|}
\hline \multirow{2}{*}{ Component } & \multirow{2}{*}{ Function } & \multicolumn{4}{|c|}{ Formulation } \\
\hline & & PLR1 * & PLR2 ** & PLR3 * & PLR4 ** \\
\hline Stearic acid & Solid lipid & 9 & 9 & 9 & 9 \\
\hline Oleic acid & Liquid lipid & 1 & 1 & 1 & 1 \\
\hline Whey Protein & Drving carrier & 5 & 5 & - & - \\
\hline Gum Arabic & Drying carrier & - & - & 5 & 5 \\
\hline $\begin{array}{c}\text { Rosemary } \\
\text { extract }\end{array}$ & $\begin{array}{l}\text { Antioxidants } \\
\text { source }\end{array}$ & 2 & 2 & 2 & 2 \\
\hline Ethanol & - & 5 & 5 & 5 & 5 \\
\hline Water & Solvent & 78 & 78 & 78 & 78 \\
\hline
\end{tabular}

* Containing the surfactant Poloxamer 188 in the concentration of $10 \%$ of the amount of lipid; ${ }^{* *}$ Containing the surfactant Poloxamer 188 in the concentration of $50 \%$ of the amount of lipid.

\subsection{Drying of Lipid Compositions}

The lipid dispersions were dried in a bench-top SD-05 spray-dryer (Lab-Plant Ltd., Filey, North Yourkshire, UK) and the spray-drying conditions were based on Cortés-Rojas et al. with some modifications [41]. Operating conditions were set as the feed flow rate of $4 \mathrm{~g} / \mathrm{min}$, through an atomizer with an orifice of $0.5 \mathrm{~mm}$, inlet gas temperature at $90{ }^{\circ} \mathrm{C}$, drying gas flow rate $60 \mathrm{~m}^{3} / \mathrm{h}$, pressure and spray gas flow of $3 \mathrm{kgf} / \mathrm{cm}^{2}$ and $17 \mathrm{Lpm}$, respectively. 


\subsection{Moisture Content and Water Activity}

For the determination of moisture content, an amount of $100 \mathrm{mg}$ of powder was taken in a Karl Fischer 870 Titrino Plus Methrom (Herisau, Switzerland), immediately after spray-drying. Water activity was measured in an Aqua Lab $4 \mathrm{Tev}^{\circledR}$ equipment (Decagon devices, Pullman, WA, USA) using the dew point sensor. Results are results expressed as the mean and standard deviation of triplicate measurements [58].

\subsection{Spray-Dried Product Recovery}

The efficiency of the spray-drying process was evaluated through the determination of product recovery $(\mathrm{R})$. This parameter, defined as the ratio between the total amount of powder recovered after drying and the mass of formulation fed to the system, was evaluated using a mass balance according to Equation (1).

$$
R(\%)=\frac{M_{c} \times\left(1-X_{p}\right)}{W_{s} \times C_{s} \times \theta} \times 100
$$

where $M_{c}$, the mass of collected powder (g); $X_{p}$, powder moisture content $(\mathrm{g}) ; W_{s}$, liquid formulation feed rate $(\mathrm{g} / \mathrm{min}) ; C_{S}$, solid content of the feed liquid formulation $(\mathrm{g} / \mathrm{g})$; and $\theta$, process time $(\mathrm{min})$.

\subsection{Analytical Evaluation of Flow Properties}

Flowability of powders was determined by calculating the Hausner Ratio (HR) and Carr's Index (CI), from the bulk density $\left(d_{0}\right.$, where $\left.d_{0}=\mathrm{m}_{0} / \mathrm{V}_{0}\right)$ and tapped bulk density $\left(d_{1250}\right.$, where $d_{1250}$ is powder density after tapping the probe 1250 times), according to Equations (2) and (3).

$$
\begin{gathered}
H R=\frac{d_{1250}}{d_{0}} \\
C I=\frac{d_{1250}-d_{0}}{d_{1250}} \times 100
\end{gathered}
$$

The analysis was performed in a Caleva ${ }^{\circledR}$ Tapped Density Tester Type TDT (Frankfurt, Germany), with a distance of $14.0 \mathrm{~mm}$ for the tapping probe [27].

\subsection{Particle Size and Particle Distribution}

To evaluate the powder particle size, an aliquot of dried samples was dissolved in ultrapure water at a ratio of 1:25 (p/v) and the analysis was performed by laser diffractometry in a Light Scattering Beckman Coulter LS 13,320 (Brea, CA, USA), equipped with a liquid module for determination of the particle size range between $0.017 \mu \mathrm{m}$ and $2000 \mu \mathrm{m}$. The obtained data were evaluated using volume distribution. After dilutions, the samples were subjected to mechanical stirring for $20 \mathrm{~min}$ and subsequently processed in the ultrasonic probe Vibracell (model VC750-SONICS, Newtown, PA, USA) with the microtip probe $1 / 8^{\prime \prime}$, at $20 \mathrm{kHz}$ of frequency and $30 \%$ of intensity for $30 \mathrm{~s}$. An optical microscope (Olympus-model BX60MIV, Tokyo, Japan) coupled to an image analyzer software (Image-Pro Plus 4.5, Media Cybernetics Inc., Bethesda, Rockville, MD, USA) was used for determination of the particle distribution of the microcapsules. The images were obtained with an increase of 50 and 500 times. The number of particles was counted according to the mean particle diameter of 0 to $200 \mu \mathrm{m}$.

\subsection{Water Solubility Study}

Evaluation of water solubility of powders was performed as described by Cano-Chauca et al. with some modifications [59]. Shortly, aliquots of $0.5 \mathrm{~g}$ of each powder were precisely weighed and dissolved in water $(50 \mathrm{~mL})$ before the homogenization under magnetic stirring for $10 \mathrm{~min}$ at $900 \mathrm{rpm}$. Afterward, the samples were centrifuged (Eppendorf model 5430 R, Eppendorf, Hamburg, Germany) 
at $2330 \mathrm{~g}$ for $5 \mathrm{~min}$ and an aliquot of the supernatant $(15 \mathrm{~mL})$ was withdrawn and placed in a tared Petri dish. The total solid content was determined after $5 \mathrm{~h}$ of oven drying at $105^{\circ} \mathrm{C}$.

\subsection{Particle Morphology of Microcapsules}

Scanning electron microscopy with field emission (Inspect F-50, FEI, Eindhoven, Nederland) was performed to visualize the morphological aspects of particles. Samples were mounted onto stubs with double-sided adhesive tape and a thin layer of platinum was applied to the surface of the particles to increase the conductivity and the analysis was made at $5 \mathrm{kV}$.

\subsection{Antioxidant Activity}

The antioxidant capacity analysis was performed in an Agilent 8453 diode array UV-Visible spectrophotometer (Agilent Life Sciences and Chemical Analysis, Santa Clara, CA, USA), as described by [60]. Briefly, ABTS radical cation (ABTS ${ }^{\bullet+}$ ) was produced by reacting $7 \mathrm{mM}$ ABTS stock solution and $2.45 \mathrm{mM}$ potassium persulphate after incubation in the dark, at room temperature during $16 \mathrm{~h}$. The $\mathrm{ABTS}^{\bullet+}$ solution was diluted with ethanol to reach an absorbance of $0.700 \pm 0.020$ at $734 \mathrm{~nm}$. After the proper dilution of the sample (ethanol mixed with $3 \mathrm{~mL}$ of diluted ABTS ${ }^{\bullet+}$ solution), the absorbance reading was taken at $734 \mathrm{~nm}$ exactly $1 \mathrm{~min}$ after initial mixing and up to $6 \mathrm{~min}$. Ethanol was used as blank and standard solutions in concentrations from 0 to $19.8 \mu \mathrm{m}$ were used for the construction of the Trolox calibration curve. The concentration of Trolox for the standard reference solution was used to calculate the percentage of inhibition of absorbance at $734 \mathrm{~nm}$, plotted as a function of Trolox concentration for the standard reference data. The absorbance of the calibrated Trolox standard solution was compared to the resulting oxidized solution. Results were expressed as $\mu \mathrm{mol}$ Trolox equivalents/g of plant extract (TEAC) using the calibration curve of Trolox.

\subsection{Statistical Analysis}

Statistical analysis was carried out using one-way analysis of variance (ANOVA) with Tukey post hoc test to identify significant differences between means $(p<0.05)$, employing the software GraphPad ${ }^{\circledR}$ Prism 8.

\section{Results and Discussion}

To obtain information about the impact of the composition on the spray-drying performance, we determined the product recoveries $(\mathrm{R})$ during the spray-drying process of four different formulations (PLR1, PLR2, PLR3, and PLR4), as represented in Figure 1. Three drying processes were performed for each formulation. The association of whey protein and the low concentration of Poloxamer (PLR1) resulted in the highest powder recovery among the evaluated samples. Notwithstanding, this formulation presented high viscosity, which made it difficult to atomize in spray-drying. In this way, it was heated at $45^{\circ} \mathrm{C}$ during the atomization process, to avoid the blockage of the atomizing system; this step might have influenced the process yield. Except for PLR1, the formulations presented a very similar drying yield. Powdered products showed similar macroscopic appearance, except for PLR2 formulation, which presented a darker, hygroscopic, and granular powder (Figure 2). 


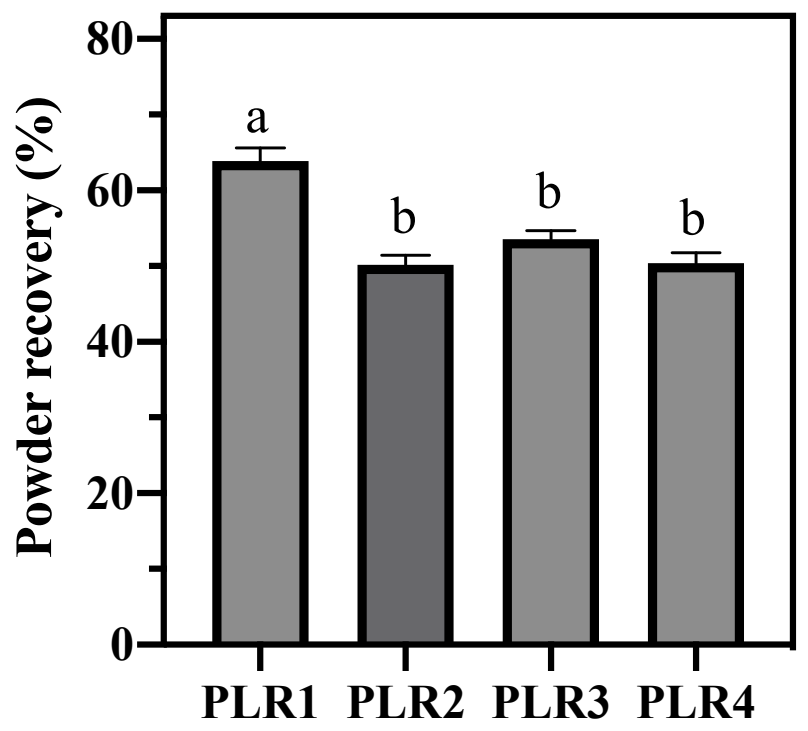

Figure 1. Powder recovery of spray-dried lipid dispersions $(n=3)$. Same letter means no significant difference according to Tukey's multiple comparison test $(p<0.05)$.

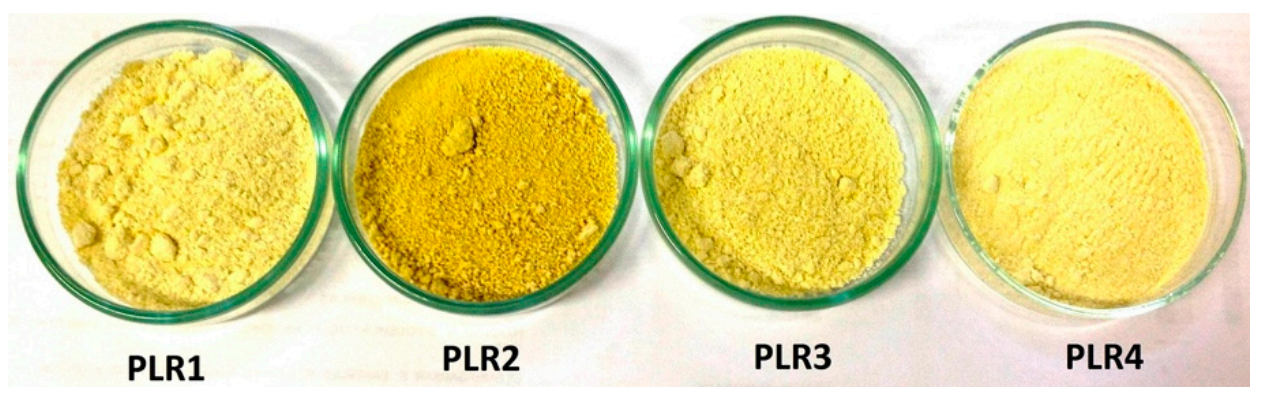

Figure 2. Appearance of spray-dried formulations.

\subsection{Solubility Test}

The aqueous solubility of spray-dried samples is shown in Figure 3, whose analyzed samples were obtained by a single drying process for each formulation. The results showed that the formulation containing whey protein and a high concentration of Poloxamer (PLR2) is the most water-soluble sample among those analyzed. Poloxamers, a class of water-soluble nonionic surfactants, are block copolymers of polyoxyethylene-polypropylene with an amphiphilic character. These polymers find use in many applications that require a wetting or solubilizing agent and surface adsorption excipients. They are frequently employed as excipients for pharmaceuticals to facilitate solubilization, dissolution, and bioavailability of poorly water-soluble compounds [53]. It was observed, as expected, that a high concentration of Poloxamer increases the water solubility of the formulations. The association of gum Arabic and low concentration of Poloxamer (PLR3) resulted in a powder insoluble in water. Some previous literature reports have indicated a correlation between the surface morphology of the particles and the instant powder solubility [59,61]. Highly ordered particles generally present lower solubility. Gombas et al. (2003) reported that crystalline and amorphous particles also differ physicochemically concerning the size and shape of the particles, solubility in water, hygroscopicity, and flow properties. Despite that we have not directly determined the crystallinity of the obtained particles, the flow properties (poor flow) and the morphology of particles (higher degree of uniformity regarding the rounded shape) presented by PLR3 particles endorses its insolubility in comparison to other formulations. Regarding the drying carriers, the results pointed to considerably higher water solubility for the formulations containing whey protein (PLR1 and PLR2) when compared to those containing gum Arabic (PLR3 and PLR4). 


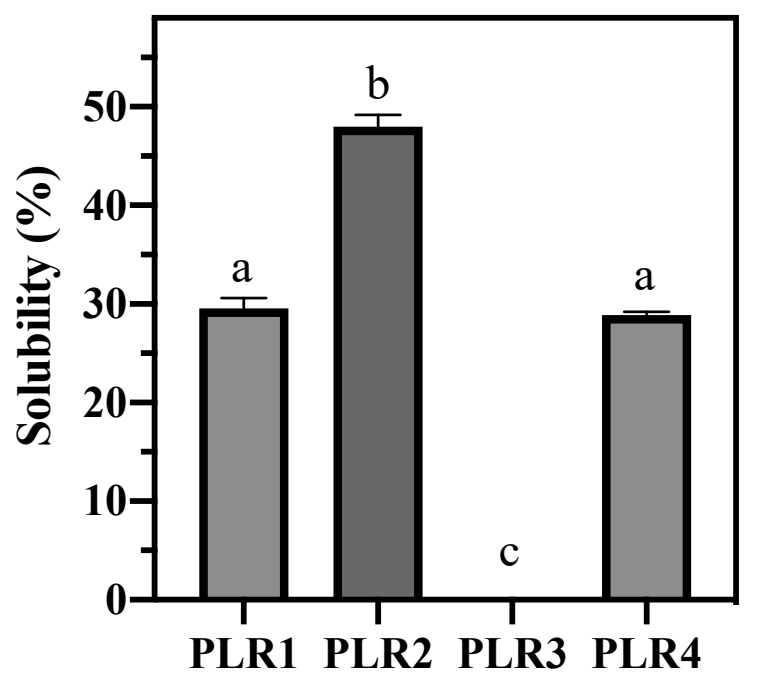

Figure 3. Water solubility of spray-dried powders. Same letter means no significant difference according to Tukey's multiple comparison test $(p<0.05)$.

\subsection{Powder Characterization and Flow Properties}

The powder properties, present in Tables 2 and 3, show a small variation in particle size, which was within the expected range for spray-dried powders [58]. The size distribution was calculated based in the particle size in the percentages of $10 \%, 50 \%$ and $90 \%$, and the span, defined as presented in Equation (4), where $\mathrm{dx}$ is a particle size value such that, in a cumulative distribution, $\mathrm{x} \%$ of the particles have a smaller size [62]. It can be observed that the span values were very similar for the formulations with whey protein, the same occurs for formulations containing gum Arabic in the composition, which indicates similar polydispersity between the formulations with the same drying carrier. The high standard deviation found for the particles is justified by the method of analysis used. The values are expressed in volume, which biased the result with the presence of a small number of larger particles, as is the case. Our raw data demonstrate high values of $d_{100}$, in the range of a few tens of $\mu \mathrm{m}$ (data not shown), which influences the standard deviation values.

$$
\text { Span }=\frac{d_{90}-d_{10}}{d_{50}}
$$

Table 2. Laser diffractometry (LD) diameters distribution of spray-dried lipid dispersions.

\begin{tabular}{ccccc}
\hline Form & Particle Size $(\mu \mathrm{m})$ & $\mathbf{d}_{\mathbf{1 0}}$ & $\begin{array}{c}\text { LD }(\boldsymbol{\mu m}) \\
\mathbf{d}_{\mathbf{5 0}}\end{array}$ & $\mathbf{d}_{\mathbf{9 0}}$ \\
\hline PLR1 & $0.764 \pm 0.627$ & 0.43 & 0.61 & 1.17 \\
PLR2 & $0.747 \pm 0.609$ & 0.43 & 0.61 & 1.16 \\
PLR3 & $0.759 \pm 0.612$ & 0.43 & 0.61 & 1.19 \\
PLR4 & $0.772 \pm 0.631$ & 0.43 & 0.62 & 1.22 \\
\hline
\end{tabular}

Table 3. Powder characterization (optical micrography) and flow properties of spray-dried lipid dispersions.

\begin{tabular}{|c|c|c|c|c|c|c|c|c|}
\hline \multirow{2}{*}{ Form } & \multicolumn{4}{|c|}{ Particle Distribution $(\mu \mathrm{m})$} & \multirow{2}{*}{$\begin{array}{c}\text { Hausner } \\
\text { Ratio (-) }\end{array}$} & \multirow{2}{*}{$\begin{array}{c}\text { Carr Index } \\
(\%)\end{array}$} & \multirow{2}{*}{$\begin{array}{c}\text { Moisture } \\
\text { Content (\%) }\end{array}$} & \multirow{2}{*}{$\begin{array}{c}\text { Water } \\
\text { Activity (-) }\end{array}$} \\
\hline & $d_{10}$ & $\mathrm{~d}_{50}$ & $d_{90}$ & Span (-) & & & & \\
\hline PLR1 & 1.28 & 4.95 & 12.77 & 2.37 & 1.2 & 20.0 & $2.94 \pm 0.11$ & $0.398 \pm 0.016$ \\
\hline PLR2 & 2.07 & 6.07 & 15.69 & 2.24 & 1.1 & 6.1 & $2.79 \pm 0.29$ & $0.447 \pm 0.005$ \\
\hline PLR3 & 2.26 & 5.85 & 12.69 & 1.78 & 1.2 & 25.0 & $2.32 \pm 0.25$ & $0.291 \pm 0.056$ \\
\hline PLR4 & 2.09 & 6.17 & 14.32 & 1.98 & 1.2 & 16.7 & $2.24 \pm 0.01$ & $0.259 \pm 0.031$ \\
\hline
\end{tabular}


The flow properties were determined based on tapped and bulk powders densities, which were calculated by the Hausner Ratio (HR) and Carr Index (CI). Both of these factors are related to particle flowability and are based on characteristics such as friction and accommodation of particles, factors that in turn are affected by the size, shape, and surface characteristics of the particles. The greater values indicate high cohesiveness and therefore, weak flow [41,63]. Hausner ratio values above 1.2 characterize a good flow. Carr index classifies the flowability of the powders according to intervals [64]:

1. Between $5 \%$ and $15 \%$ : excellent flow;

2. Between $12 \%$ to $16 \%$ : good flow;

3. Between $18 \%$ to $21 \%$ : scarce flow;

4. Between $23 \%$ to $35 \%$ : poor flow;

5. Between $33 \%$ to $38 \%$ : very poor flow;

6. Higher than $40 \%$ : extremely poor flow.

Incorporation of a higher concentration of Poloxamer has been shown to reduce the cohesiveness and improve the flowability of the spray-dried powders, once both PLR2 and PLR4 exhibit excellent and good flow respectively (Table 3). Nevertheless, both formulations containing a smaller amount of Poloxamer (PLR1 and PLR3) presented scarce and weak flow. The flowability of the powders was also dependent on the type of drying carrier used. Formulations containing whey protein (PLR1/PLR2) provided better flowable powders. The higher particle size distribution $\left(\mathrm{d}_{90}\right)$ presented by the samples containing whey protein, when compared to the corresponding samples with Arabic gum, support this result. The presence of whey protein concentrate in the feed material increases its viscosity, which results in a powder with bigger particles [65]. Furthermore, it is well known that mean particle size, shape, and particle size distribution are characteristics strictly related to the flow properties [66]. The increase in mean particle size tends to reduce the cohesiveness between the powder particles, which results in increased flowability [65].

Other important parameters to consider when characterizing powders are moisture content and water activity. PLR1 and PLR2 powders presented higher values for both moisture content and water activity. This can be attributed to the fact that proteins in an amorphous state hold an increased capacity to incorporate water molecules, which increases the moisture content and, indirectly, the water activity. Our findings are in agreement with a previous study from Bhusari et al. (2014) comparing different carrier agents to investigate their effect on the physicochemical properties of spray-dried powders [65].

In general, the limited flowability presented by the powders is normally obtained for spray-dried powders and corroborate with results previously found by our research group [67]. These findings are closely related to the stickiness of the lipid formulations to the drying chamber of the equipment [41]. The high temperature used for the spray-drying process, even for a short time, is sufficient to melt the lipid components of the formulations, favoring the powder adherence to the walls of the drying chamber and the cyclone. The drying carriers assist in this process by increasing the glass transition temperature of the lipids and improving the powder flow by increasing its density [37,41,64].

Figure 4 represents the particle morphology of lipid-based powders. The morphology of the spray-dried particles is directly related to drying conditions and the constituents of the encapsulating composition [41]. The physicochemical properties of the material to be atomized in the spray-drying partially determine the drying behavior and particle morphology of the final product [68]. The powders showed particles in different sizes, confirming the results obtained for particle size distribution. Surface analysis of the particles revealed a rounded shape with a rough and shriveled external surface, typical of spray-dried powders [69]. The shriveled and rough surfaces were more pronounced for the powders containing whey protein in the composition (A and B). These findings can be related to the protein fraction and agree with the findings of Bhusari et al. (2014) [65] and Faldt and Bergenstahl (1994) [70] that related the shriveled surface of the particles to the characteristic of protein-rich spray-dried powders. Furthermore, Anandharamakrishnan et al. [71] found that whey protein solution spray-dried at high temperature $\left(100-120^{\circ} \mathrm{C}\right)$ presented irregularly shaped particles, which confirms 
that mild temperatures, around $60-80^{\circ} \mathrm{C}$, are suitable to avoid protein denaturation. Particles of regular surface are usually preferred as they contribute to improving the flowing properties of the powders.

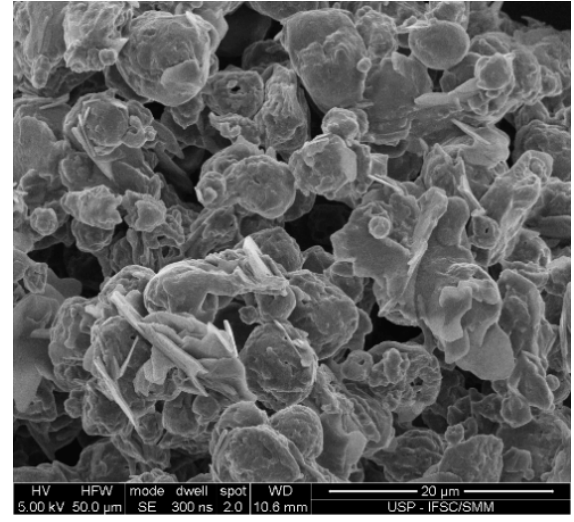

(A)

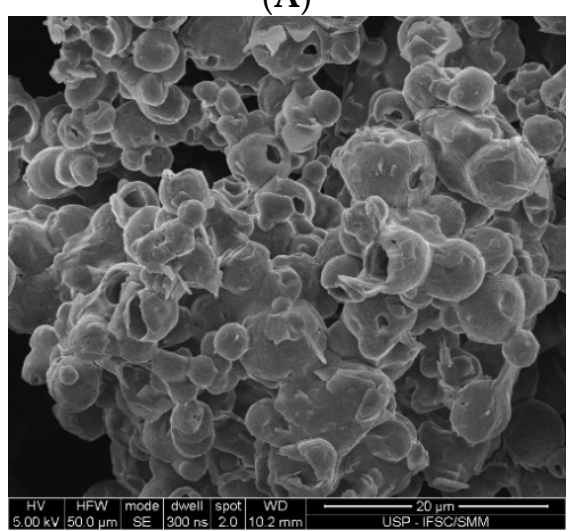

(C)

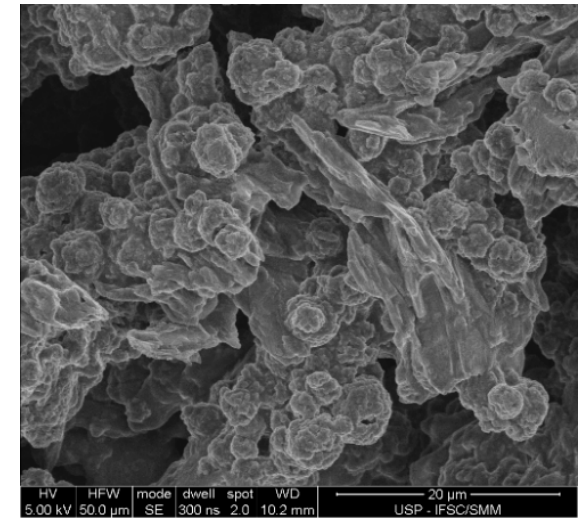

(B)

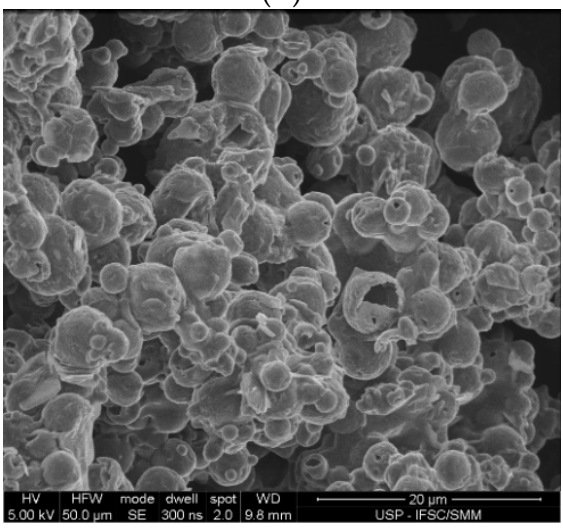

(D)

Figure 4. Particle morphology of spray-dried lipid carriers: PLR1 (A), PLR2 (B), PLR3 (C) and PLR4 (D).

\subsection{Antioxidant Properties of Lipid Carriers}

The in vitro antioxidant profile of the spray-dried lipid carriers was measured right after preparation and the results are presented in Figure 5. The non-encapsulated lyophilized extract, as expected, presented a very high antioxidant activity $(1356 \pm 91 \mu \mathrm{mol}$ Trolox/mg powder-data not shown). The differences between the compositions of the lipid systems provided distinct values for antioxidant activity, which may affect the release of the antioxidant molecules to the reaction medium. At $p<0.05$ the differences between the formulations PLR2, PLR3, and PLR4 were not statistically significant. On the other hand, all of these formulations showed antioxidant activity statistically superior to PLR1, which demonstrates that the combination of whey protein and low concentration of surfactant (Poloxamer) resulted in a product with reduced antioxidant activity. Our results are in good agreement with the research findings reported by the different researchers [68-70], which reported the increment in the antioxidant activity by increasing the concentration of antioxidants molecules into the aqueous phase of emulsions by surfactant micelles. This mechanism is related to the ability of surfactant micelles in solubilizing the antioxidant molecules out of the emulsion droplet core, where the molecule is inefficient as an antioxidant [72]. 


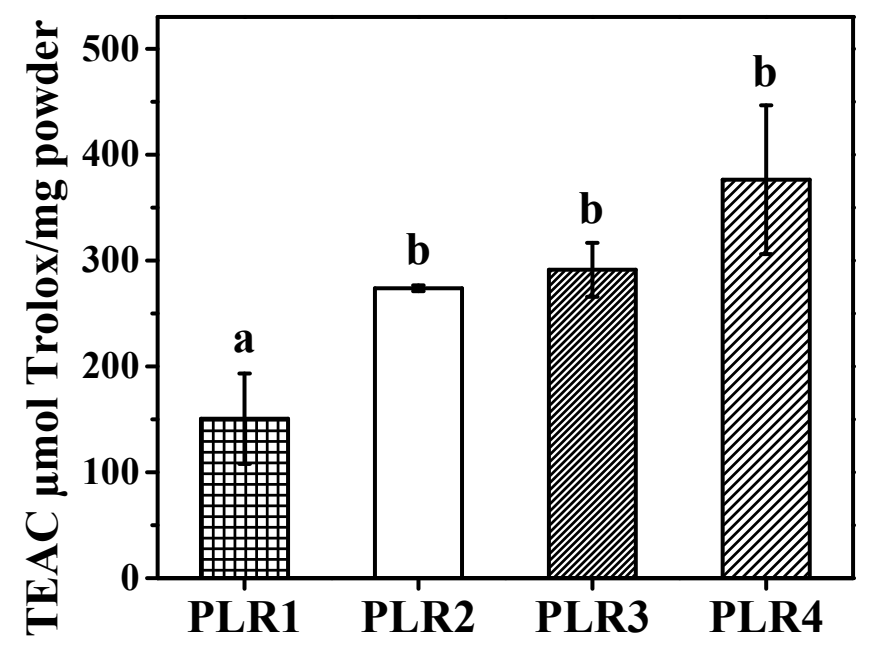

Figure 5. Antioxidant profile of spray-dried lipid carriers expressed as Trolox equivalents per mg of powder. Same letter means significantly different in Tukey's multiple comparison test $(p<0.05)$.

\section{Conclusions}

Powdered redispersible lipid-based compositions entrapping antioxidants from Rosmarinus officinalis extract were successfully generated by spray-drying. Our study has been a preliminary assessment on the evaluation of the influence of selected drying adjuvants (whey protein and gum Arabic) and surfactant concentration (Poloxamer 188) on the spray-drying process, powder properties, and antioxidant profile of the dried lipid carriers. Both the surfactant concentration and type of drying adjuvants influenced the physical properties and antioxidant activity of the final product. The association of whey protein and the low concentration of poloxamer resulted in a highly viscous formulation, difficult to be atomized in the spray-drying. Despite similar particle size and polydispersity between the powders, the formulation containing a higher concentration of poloxamer and whey protein showed the best flow properties; however, morphologically formulations with gum Arabic showed homogeneously rounded particles. The spray-dried product exhibited high antioxidant activity, mainly the formulations containing gum Arabic and higher poloxamer concentration, anticipating its potential use as a natural preservative in foodstuff and as a nutraceutical. Besides, recognizing that selected adjuvants do influence the outcomes of the production, a full factorial design experiment can be proposed to describe the best conditions to achieve the highest product recovery.

Author Contributions: Contributed to the methodology, formal analysis, investigation, resources, and data curation: I.B., C.R.F.S., A.D., M.L., and A.S.; writing of the original manuscript: I.B., C.R.F.S., E.B.S., and W.P.O.; conceptualization, review and editing of the manuscript, project administration, supervision, and funding acquisition: I.B., E.B.S., A.S., and W.P.O. All authors have made a substantial contribution to the work and have approved its publication. All authors have read and agreed to the published version of the manuscript.

Funding: This research has been sponsored by CAPES (Coordenação de Aperfeiçoamento de Pessoal de Nível Superior) through the financial support (88887.368385/2019-00) granted to I.B., by the São Paulo Research Foundation (FAPESP) through the financial support (Grant N. 2018/26069-0 and 2011/10333-1) granted to W.P.O. and by the Portuguese Science and Technology Foundation (FCT) through the projects M-ERA-NET/0004/2015 (PAIRED) and UIDB/04469/2020 (strategic fund) granted to E.B.S.

Acknowledgments: I.B. acknowledges Giovanni Raspantini for his contribution to data analysis.

Conflicts of Interest: The authors report no conflict of interest in this study.

\section{References}

1. Souto, E.B.; Sampaio, A.C.; Campos, J.R.; Martins-Gomes, C.; Aires, A.; Silva, A.M. Chapter 2-Polyphenols for skin cancer: Chemical properties, structure-related mechanisms of action and new delivery systems. In Studies in Natural Products Chemistry; Atta ur, R., Ed.; Elsevier: Amsterdam, The Netherlands, 2019; Volume 63, pp. 21-42. 
2. Durazzo, A.; Lucarini, M.; Souto, E.B.; Cicala, C.; Caiazzo, E.; Izzo, A.A.; Novellino, E.; Santini, A. Polyphenols: A concise overview on the chemistry, occurrence, and human health. Phytother Res. 2019, 33, 2221-2243. [CrossRef]

3. Durazzo, A.; Lucarini, M.; Novellino, E.; Souto, E.B.; Daliu, P.; Santini, A. Abelmoschus esculentus (L.): Bioactive Components' Beneficial Properties-Focused on Antidiabetic Role-For Sustainable Health Applications. Molecules 2018, 24, 38. [CrossRef]

4. Nazhand, A.; Lucarini, M.; Durazzo, A.; Zaccardelli, M.; Cristarella, S.; Souto, S.B.; Silva, A.M.; Severino, P.; Souto, E.B.; Santini, A. Hawthorn (Crataegus spp.): An Updated Overview on Its Beneficial Properties. Forests 2020, 11, 564. [CrossRef]

5. Cefali, L.C.; Ataide, J.A.; Eberlin, S.; da Silva Gonçalves, F.C.; Fernandes, A.R.; Marto, J.; Ribeiro, H.M.; Foglio, M.A.; Mazzola, P.G.; Souto, E.B. In Vitro SPF and Photostability Assays of Emulsion Containing Nanoparticles with Vegetable Extracts Rich in Flavonoids. AAPS Pharm. Sci. Tech. 2019, 20, 9. [CrossRef]

6. Cefali, L.C.; Ataide, J.A.; Fernandes, A.R.; Sanchez-Lopez, E.; Sousa, I.M.O.; Figueiredo, M.C.; Ruiz, A.; Foglio, M.A.; Mazzola, P.G.; Souto, E.B. Evaluation of In Vitro Solar Protection Factor (SPF), Antioxidant Activity, and Cell Viability of Mixed Vegetable Extracts from Dirmophandra mollis Benth, Ginkgo biloba L., Ruta graveolens L., and Vitis vinifera L. Plants 2019, 8, 453. [CrossRef]

7. Cefali, L.C.; Ataide, J.A.; Fernandes, A.R.; Sousa, I.M.O.; Goncalves, F.; Eberlin, S.; Davila, J.L.; Jozala, A.F.; Chaud, M.V.; Sanchez-Lopez, E.; et al. Flavonoid-Enriched Plant-Extract-Loaded Emulsion: A Novel Phytocosmetic Sunscreen Formulation with Antioxidant Properties. Antioxidants 2019, 8, 443. [CrossRef]

8. Pimentel-Moral, S.; Teixeira, M.C.; Fernandes, A.R.; Arraez-Roman, D.; Martinez-Ferez, A.; Segura-Carretero, A.; Souto, E.B. Lipid nanocarriers for the loading of polyphenols-A comprehensive review. Adv. Colloid Interface Sci. 2018, 260, 85-94. [CrossRef] [PubMed]

9. Souto, E.B.; Zielinska, A.; Souto, S.B.; Durazzo, A.; Lucarini, M.; Santini, A.; Silva, A.M.; Atanasov, A.G.; Marques, C.; Andrade, L.N.; et al. (+)-Limonene 1,2-epoxide-loaded SLN: Evaluation of drug release, antioxidant activity and cytotoxicity in HaCaT cell line. Int. J. Mol. Sci. 2020, 21, 1449. [CrossRef] [PubMed]

10. Souto, E.B.; Souto, S.B.; Zielinska, A.; Durazzo, A.; Lucarini, M.; Santini, A.; Horbańczuk, O.K.; Atanasov, A.G.; Marques, C.; Andrade, L.N.; et al. Perillaldehyde 1,2-epoxide loaded SLN-tailored mAb: Production, physicochemical characterization and in vitro cytotoxicity profile in MCF-7 cell lines. Pharmaceutics 2020, 12, 161. [CrossRef] [PubMed]

11. Wardhani, D.H.; Vázquez, J.A.; Pandiella, S.S. Optimisation of antioxidants extraction from soybeans fermented by Aspergillus oryzae. Food Chem. 2010, 118, 731-739. [CrossRef]

12. Rodríguez-Rojo, S.; Visentin, A.; Maestri, D.; Cocero, M.J. Assisted extraction of rosemary antioxidants with green solvents. J. Food Eng. 2012, 109, 98-103. [CrossRef]

13. Li, Y.; Seacat, A.; Kuppusamy, P.; Zweier, J.L.; Yager, J.D.; Trush, M.A. Copper redox-dependent activation of 2-tert-butyl $(1,4)$ hydroquinone: Formation of reactive oxygen species and induction of oxidative DNA damage in isolated DNA and cultured rat hepatocytes. Mutat. Res. Genet. Toxicol. Environ. Mutagenesis 2002, 518, 123-133. [CrossRef]

14. Vandghanooni, S.; Forouharmehr, A.; Eskandani, M.; Barzegari, A.; Kafil, V.; Kashanian, S.; Ezzati Nazhad Dolatabadi, J. Cytotoxicity and DNA fragmentation properties of butylated hydroxyanisole. DNA Cell Biol. 2013, 32, 98-103. [CrossRef] [PubMed]

15. Campos, J.R.; Severino, P.; Ferreira, C.S.; Zielinska, A.; Santini, A.; Souto, S.B.; Souto, E.B. Linseed Essential Oil-Source of Lipids as Active Ingredients for Pharmaceuticals and Nutraceuticals. Curr. Med. Chem. 2019, 26, 4537-4558. [CrossRef] [PubMed]

16. Carbone, C.; Martins-Gomes, C.; Caddeo, C.; Silva, A.M.; Musumeci, T.; Pignatello, R.; Puglisi, G.; Souto, E.B. Mediterranean essential oils as precious matrix components and active ingredients of lipid nanoparticles. Int. J. Pharm. 2018, 548, 217-226. [CrossRef] [PubMed]

17. Pereira, I.; Zielinska, A.; Ferreira, N.R.; Silva, A.M.; Souto, E.B. Optimization of linalool-loaded solid lipid nanoparticles using experimental factorial design and long-term stability studies with a new centrifugal sedimentation method. Int. J. Pharm. 2018, 549, 261-270. [CrossRef] [PubMed]

18. Severino, P.; Andreani, T.; Chaud, M.V.; Benites, C.I.; Pinho, S.C.; Souto, E.B. Essential oils as active ingredients of lipid nanocarriers for chemotherapeutic use. Curr. Pharm. Biotechnol. 2015, 16, 365-370. [CrossRef] [PubMed]

19. Vieira, R.; Severino, P.; Nalone, L.A.; Souto, S.B.; Silva, A.M.; Lucarini, M.; Durazzo, A.; Santini, A.; Souto, E.B. Sucupira Oil-Loaded Nanostructured Lipid Carriers (NLC): Lipid Screening, Factorial Design, Release Profile, and Cytotoxicity. Molecules 2020, 25, 685. [CrossRef] 
20. Zielinska, A.; Ferreira, N.R.; Durazzo, A.; Lucarini, M.; Cicero, N.; Mamouni, S.E.; Silva, A.M.; Nowak, I.; Santini, A.; Souto, E.B. Development and Optimization of Alpha-Pinene-Loaded Solid Lipid Nanoparticles (SLN) Using Experimental Factorial Design and Dispersion Analysis. Molecules 2019, 24, 2683. [CrossRef]

21. Zielińska, A.; Ferreira, N.R.; Feliczak-Guzik, A.; Nowak, I.; Souto, E.B. Loading, release profile and accelerated stability assessment of monoterpenes-loaded Solid Lipid Nanoparticles (SLN). Pharm. Dev. Technol. 2020. [CrossRef]

22. Zielinska, A.; Martins-Gomes, C.; Ferreira, N.R.; Silva, A.M.; Nowak, I.; Souto, E.B. Anti-inflammatory and anti-cancer activity of citral: Optimization of citral-loaded solid lipid nanoparticles (SLN) using experimental factorial design and LUMiSizer(R). Int. J. Pharm. 2018, 553, 428-440. [CrossRef] [PubMed]

23. Sharifi-Rad, J.; Ezzat, S.M.; El Bishbishy, M.H.; Mnayer, D.; Sharopov, F.; Kılıç, C.S.; Neagu, M.; Constantin, C.; Sharifi-Rad, M.; Atanassova, M.; et al. Rosmarinus plants: Key farm concepts towards food applications. Phytother. Res. 2020, 34, 1474-1518. [CrossRef] [PubMed]

24. Bourhia, M.; Laasri, F.E.; Aourik, H.; Boukhris, A.; Ullah, R.; Bari, A.; Ali, S.S.; El Mzibri, M.; Benbacer, L.; Gmouh, S. Antioxidant and Antiproliferative Activities of Bioactive Compounds Contained in Rosmarinus officinalis Used in the Mediterranean Diet. Evid. Based Complement. Altern. Med. 2019, 2019, 7623830. [CrossRef] [PubMed]

25. Borges, R.S.; Ortiz, B.L.S.; Pereira, A.C.M.; Keita, H.; Carvalho, J.C.T. Rosmarinus officinalis essential oil: A review of its phytochemistry, anti-inflammatory activity, and mechanisms of action involved. J. Ethnopharmacol. 2019, 229, 29-45. [CrossRef]

26. Lee, C.J.; Chen, L.G.; Chang, T.L.; Ke, W.M.; Lo, Y.F.; Wang, C.C. The correlation between skin-care effects and phytochemical contents in Lamiaceae plants. Food Chem. 2011, 124, 833-841. [CrossRef]

27. Hamre, K.; Kolås, K.; Sandnes, K. Protection of fish feed, made directly from marine raw materials, with natural antioxidants. Food Chem. 2010, 119, 270-278. [CrossRef]

28. Carbone, C.; Teixeira, M.D.C.; Sousa, M.D.C.; Martins-Gomes, C.; Silva, A.M.; Souto, E.M.B.; Musumeci, T. Clotrimazole-Loaded Mediterranean Essential Oils NLC: A Synergic Treatment of Candida Skin Infections. Pharmaceutics 2019, 11, 231. [CrossRef]

29. Ahmed, H.M.; Babakir-Mina, M. Investigation of rosemary herbal extracts (Rosmarinus officinalis) and their potential effects on immunity. Phytother. Res. 2020. [CrossRef]

30. Su, J.; Jia, F.; Lu, J.; Chen, W.; Sun, H.; Liu, T.; Wu, X. Characterization of the metabolites of rosmarinic acid in human liver microsomes using liquid chromatography combined with electrospray ionization tandem mass spectrometry. Biomed. Chromatogr. BMC 2020, 34, e4806. [CrossRef]

31. Thorsen, M.A.; Hildebrandt, K.S. Quantitative determination of phenolic diterpenes in rosemary extracts: Aspects of accurate quantification. J. Chromatogr. A 2003, 995, 119-125. [CrossRef]

32. Durazzo, A.; Lucarini, M. Extractable and Non-Extractable Antioxidants. Molecules 2019, $24,1933$. [CrossRef] [PubMed]

33. Tabart, J.; Kevers, C.; Pincemail, J.; Defraigne, J.O.; Dommes, J. Comparative antioxidant capacities of phenolic compounds measured by various tests. Food Chem. 2009, 113, 1226-1233. [CrossRef]

34. Bankole, V.O.; Osungunna, M.O.; Souza, C.R.F.; Salvador, S.L.; Oliveira, W.P. Spray-Dried Proliposomes: An Innovative Method for Encapsulation of Rosmarinus officinalis L. Polyphenols. AAPS PharmSciTech 2020, 21, 143. [CrossRef] [PubMed]

35. Boonme, P.; Kaewbanjong, J.; Amnuaikit, T.; Andreani, T.; Silva, A.M.; Souto, E.B. Microemulsion and Microemulsion-Based Gels for Topical Antifungal Therapy with Phytochemicals. Curr. Pharm. Des. 2016, 22, 4257-4263. [CrossRef] [PubMed]

36. Oliveira, W.P.; Freitas, L.A.P.; Freire, J.T. Drying of Pharmaceutical Products. In Transport Phenomena in Particulate Systems; Oliveira, W.P., Freitas, L.A.P., Freire, J.T., Eds.; Bentham Science e-Books: Sharja, UAE, 2012. [CrossRef]

37. Bott, R.F.; Labuza, T.P.; Oliveira, W.P. Stability Testing of Spray- and Spouted Bed-Dried Extracts of Passiflora alata. Dry. Technol. 2010, 28, 1255-1265. [CrossRef]

38. Bringas-Lantigua, M.; Expósito-Molina, I.; Reineccius, G.A.; López-Hernández, O.; Pino, J.A. Influence of Spray-Dryer Air Temperatures on Encapsulated Mandarin Oil. Dry. Technol. 2011, 29, 520-526. [CrossRef]

39. Re, R.; Pellegrini, N.; Proteggente, A.; Pannala, A.; Yang, M.; Rice-Evans, C. Antioxidant activity applying an improved ABTS radical cation decolorization assay. Free Radic. Biol. Med. 1999, 26, 1231-1237. [CrossRef] 
40. Georgetti, S.R.; Casagrande, R.; Souza, C.R.F.; Oliveira, W.P.; Fonseca, M.J.V. Spray drying of the soybean extract: Effects on chemical properties and antioxidant activity. LWT Food Sci. Technol. 2008, 41, 1521-1527. [CrossRef]

41. Cortés-Rojas, D.F.; Souza, C.R.F.; Oliveira, W.P. Encapsulation of eugenol rich clove extract in solid lipid carriers. J. Food Eng. 2014, 127, 34-42. [CrossRef]

42. Kenyon, M.M. Modified Starch, Maltodextrin, and Corn Syrup Solids as Wall Materials for Food Encapsulation. In Encapsulation and Controlled Release of Food Ingredients; American Chemical Society: Washington, WA, USA, 1995; Volume 590, pp. 42-50.

43. Madene, A.; Jacquot, M.; Scher, J.; Desobry, S. Flavour encapsulation and controlled release-A review. Int. J. Food Sci. Technol. 2006, 41,1-21. [CrossRef]

44. McNamee, B.F.; O'Riorda, E.D.; O'Sullivan, M. Emulsification and Microencapsulation Properties of Gum Arabic. J. Agric. Food Chem. 1998, 46, 4551-4555. [CrossRef]

45. Fernandes, R.V.d.B.; Borges, S.V.; Botrel, D.A. Gum arabic/starch/maltodextrin/inulin as wall materials on the microencapsulation of rosemary essential oil. Carbohydr. Polym. 2014, 101, 524-532. [CrossRef] [PubMed]

46. de Vos, P.; Faas, M.M.; Spasojevic, M.; Sikkema, J. Encapsulation for preservation of functionality and targeted delivery of bioactive food components. Int. Dairy J. 2010, 20, 292-302. [CrossRef]

47. Calvo, P.; Castaño, Á.L.; Lozano, M.; González-Gómez, D. Influence of the microencapsulation on the quality parameters and shelf-life of extra-virgin olive oil encapsulated in the presence of BHT and different capsule wall components. Food Res. Int. 2012, 45, 256-261. [CrossRef]

48. Hogan, S.A.; McNamee, B.F.; O'Riordan, E.D.; O'Sullivan, M. Emulsification and microencapsulation properties of sodium caseinate/carbohydrate blends. Int. Dairy J. 2001, 11, 137-144. [CrossRef]

49. Fazaeli, M.; Emam-Djomeh, Z.; Kalbasi Ashtari, A.; Omid, M. Effect of spray drying conditions and feed composition on the physical properties of black mulberry juice powder. Food Bioprod. Process. 2012, 90, 667-675. [CrossRef]

50. Lopes, C.M.; Martins-Lopes, P.; Souto, E.B. Nanoparticulate carriers (NPC) for oral pharmaceutics and nutraceutics. Pharmazie 2010, 65, 75-82.

51. Souto, E.B.; Souto, S.B.; Campos, J.R.; Severino, P.; Pashirova, T.N.; Zakharova, L.Y.; Silva, A.M.; Durazzo, A.; Lucarini, M.; Izzo, A.A.; et al. Nanoparticle Delivery Systems in the Treatment of Diabetes Complications. Molecules 2019, 24, 4209. [CrossRef]

52. Severino, P.; Pinho, S.C.; Souto, E.B.; Santana, M.H. Polymorphism, crystallinity and hydrophilic-lipophilic balance of stearic acid and stearic acid-capric/caprylic triglyceride matrices for production of stable nanoparticles. Colloids Surf. B Biointerfaces 2011, 86, 125-130. [CrossRef]

53. Souto, E.B.; Baldim, I.; Oliveira, W.P.; Rao, R.; Yadav, N.; Gama, F.M.; Mahant, S. SLN and NLC for topical, dermal and transdermal drug delivery. Expert Opin. Drug Deliv. 2020, 17, 357-377. [CrossRef]

54. Mahant, S.; Rao, R.; Souto, E.B.; Nanda, S. Analytical tools and evaluation strategies for nanostructured lipid carrier based topical delivery systems. Expert Opin. Drug Deliv. 2020. [CrossRef] [PubMed]

55. Souto, E.B.; Doktorovova, S.; Zielinska, A.; Silva, A.M. Key production parameters for the development of solid lipid nanoparticles by high shear homogenization. Pharm. Dev. Technol. 2019, 24, 1181-1185. [CrossRef] [PubMed]

56. Souto, E.B.; Almeida, A.J.; Müller, R.H. Lipid Nanoparticles (SLN ${ }^{\circledR}$, NLC $\left.^{\circledR}\right)$ for Cutaneous Drug Delivery: Structure, Protection and Skin Effects. J. Biomed. Nanotechnol. 2007, 3, 317-331. [CrossRef]

57. Tan, S.W.; Billa, N.; Roberts, C.R.; Burley, J.C. Surfactant effects on the physical characteristics of Amphotericin B-containing nanostructured lipid carriers. Colloids Surfaces A Physicochem. Eng. Asp. 2010, 372, 73-79. [CrossRef]

58. Cortés-Rojas, D.F.; Oliveira, W.P. Physicochemical Properties of Phytopharmaceutical Preparations as Affected by Drying Methods and Carriers. Dry. Technol. 2012, 30, 921-934. [CrossRef]

59. Cano-Chauca, M.; Stringheta, P.C.; Ramos, A.M.; Cal-Vidal, J. Effect of the carriers on the microstructure of mango powder obtained by spray drying and its functional characterization. Innov. Food Sci. Emerg. Technol. 2005, 6, 420-428. [CrossRef]

60. Cortés-Rojas, D.F.; Souza, C.R.F.; Oliveira, W.P. Optimisation of the extraction of phenolic compounds and antioxidant activity from aerial parts of Bidens pilosa L. using response surface methodology. Int. J. Food Sci. Technol. 2011, 46, 2420-2427. [CrossRef]

61. Gombás, A.; Antal, I.; Szabó-Révész, P.; Marton, S.; Erõs, I. Quantitative determination of crystallinity of alpha-lactose monohydrate by Near Infrared Spectroscopy (NIRS). Int. J. Pharm. 2003, 256, 25-32. [CrossRef] 
62. Martín, Á.; Pham, H.M.; Kilzer, A.; Kareth, S.; Weidner, E. Micronization of polyethylene glycol by PGSS (Particles from Gas Saturated Solutions)-drying of aqueous solutions. Chem. Eng. Process. Process. Intensif. 2010, 49, 1259-1266. [CrossRef]

63. Venkatesh, D.N.; Meyyanathan, S.N.; Shanmugam, R.; Zielinska, A.; Campos, J.R.; Ferreira, J.D.; Souto, E.B. Development, in vitro release and in vivo bioavailability of sustained release nateglinide tablets. J. Drug Deliv. Sci. Technol. 2020, 55, 101355. [CrossRef]

64. Taylor, K.M.G.; Aulton, M.E. Pharmaceutics: The Science of Dosage Form Design, Churchill Livingstone, 2nd ed.; Churchill Livingstone: London, UK, 2001.

65. Bhusari, S.N.; Muzaffar, K.; Kumar, P. Effect of carrier agents on physical and microstructural properties of spray dried tamarind pulp powder. Powder Technol. 2014, 266, 354-364. [CrossRef]

66. Pachón-Morales, J.; Colin, J.; Casalinho, J.; Perré, P.; Puel, F. Flowability characterization of torrefied biomass powders: Static and dynamic testing. Biomass Bioenergy 2020, 138, 105608. [CrossRef]

67. Baldim, I.; Rosa, D.M.; Souza, C.R.F.; Ana, R.D.; Durazzo, A.; Lucarini, M.; Santini, A.; Souto, E.B.; Oliveira, W.P. Factors Affecting the Retention Efficiency and Physicochemical Properties of Spray Dried Lipid Nanoparticles Loaded with Lippia sidoides Essential Oil. Biomolecules 2020, 10, 693. [CrossRef] [PubMed]

68. Walton, D.E.; Mumford, C.J. The Morphology of Spray-Dried Particles: The Effect of Process Variables upon the Morphology of Spray-Dried Particles. Chem. Eng. Res. Des. 1999, 77, 442-460. [CrossRef]

69. Tonon, R.V.; Grosso, C.R.F.; Hubinger, M.D. Influence of emulsion composition and inlet air temperature on the microencapsulation of flaxseed oil by spray drying. Food Res. Int. 2011, 44, 282-289. [CrossRef]

70. Fäldt, P.; Bergenståhl, B. The surface composition of spray-dried protein-Lactose powders. Colloids Surfaces A Physicochem. Eng. Asp. 1994, 90, 183-190. [CrossRef]

71. Anandharamakrishnan, C.; Rielly, C.D.; Stapley, A.G.F. Effects of Process Variables on the Denaturation of Whey Proteins during Spray Drying. Dry. Technol. 2007, 25, 799-807. [CrossRef]

72. Kiralan, S.S.; Doğu-Baykut, E.; Kittipongpittaya, K.; McClements, D.J.; Decker, E.A. Increased Antioxidant Efficacy of Tocopherols by Surfactant Solubilization in Oil-in-Water Emulsions. J. Agric. Food Chem. 2014, 62, 10561-10566. [CrossRef] 